\title{
HAKIKAT SANKSI DALAM PERSPEKTIF HUKUM PIDANA INDONESIA DAN HUKUM PIDANA ISLAM (STUDI TENTANG PIDANA MATI)
}

\author{
Andi Istiqlal Assaad \\ Mahasiswa Program Doktor Ilmu Hukum Pascasarajana UMI Makassar \\ email : istiqlal.assaad@ymail.com
}

\begin{abstract}
Essentially criminal law sanctions in Indonesia and the Islamic criminal law can be compared by reviewing the nature of criminal law sanctions in Indonesia is to maintain / preserve the benefit of the individual. While the nature of the sanctions within the Islamic criminal law, is to keep / maintain the benefit of individuals and society.
\end{abstract}

Keywords : Sanctions Criminal Law and Criminal Law of Islam.

\begin{abstract}
Abstrak
Intinya sanksi hukum pidana di Indonesia dan hukum pidana Islam dapat dibandingkan dengan mengkaji sifat sanksi hukum pidana di Indonesia adalah dengan mempertahankan / melestarikan manfaat individu. Sedangkan sifat dari sanksi dalam hukum pidana Islam, adalah untuk menjaga / mempertahankan manfaat individu dan masyarakat.
\end{abstract}

Kata kunci: Sanksi Pidana; Pidana Islam;

\section{A. PENDAHULUAN}

Salah satu jaminan ditaatinya hukum oleh segenap masyarakat yang ditujukan hukum itu, tidak lain adalah adanya sanksi. Sanksi dalam hukum pidana dikenal antara lain berupa hukuman penjara, denda dan hukuman mati. Sanksi dalam hukum pidana Indonesia maupun hukum pidana Islam dikenal memiliki sifat-sifat, karakter dan dimensinya masing-masing. Secara teori, dimensi sanksi dalam hukum pidana Indonesia dikatakan lahiriah semata, sedangkan dalam hukum pidana Islam sifatnya bukan hanya sekedar lahiriah, akan tetapi juga berdimensi bathin dan ukhrawi.

Hukum Pidana Islam merupakan syariat Allah yang mengandung kemaslahatan bagi kehidupan manusia baik di dunia maupun akhirat. Syariat Islam dimaksud, secara materiil mengandung kewajiban asasi bagi setiap manusia untuk melaksanakannya. Konsep kewajiban asasi syariat, yaitu menempatkan Allah sebagai pemegang segala hak, baik yang ada pada diri sendiri maupun yang ada pada orang lain. Setiap orang hanya pelaksana yang berkewajiban memenuhi perintah Allah. Perintah Allah dimaksud, harus ditunaikan untuk kemaslahatan dirinya dan orang lain. ${ }^{1}$

${ }^{1}$ H.Zainuddin Ali, Hukum Pidana Islam, Sinar Grafika, Jakarta, 2012.

Vol. 19 No. 2 November 2017 
Jenis hukuman yang menyangkut tindak pidana kriminal dalam hukum pidana Islam terbagi atas dua bagian, yaitu $:^{2}$

1. Ketentuan hukuman yang pasti mengenai berat ringannya hukuman termasuk kisas dan diat yang tercantum di dalam Al-Qur'an dan hadis. Hal dimaksud disebut hudud;

2. Ketentuan hukuman yang dibuat oleh hakim, melalui putusannya yang disebut hukuman takzir. Hukum publik dalam ajaran Islam, adalah Jinayah yang memuat aturan mengenai perbuatan yang diancam dengan hukuman, baik dalam jarimah hudud maupun dalam jarimah takzir. Jarimah adalah perbuatan tindak pidana. Jarimah hudud, adalah perbuatan pidana yang mempunyai bentuk dan batas hukumannya di dalam Alquran dan Sunnah Nabi Muhammad Saw. Lain halnya jarimah takzir sebagai perbuatan pidana yang bentuk dan ancaman hukumannya ditentukan oleh penguasa (hakim) sebagai pelajaran kepada pelakunya.

Sanksi yang bersifat negatif dianggap sangat penting, karena sanksi semacam ini berpotensi untuk memberi efek protektif bagi masyarakat yang ditujukan hukum itu, dan memberi efek jera bagi pihak yang telah dikenakan sanksi hukum.

Hukum pidana dalam perkembangannya, sudah tidak berdiri sendiri, melainkan harus dihubungkan dengan nilai-nilai hak asasi manusia dan prinsip-prinsip keadilan bagi kemanusiaan. Bagaimana konsep tersebut dalam sistem hukum pidana Indonesia (yang berwatak sekuler), dan hukum Pidana Islam dikembangkan, menjadi tantangan dan menjadi perhatian bagi negara-negara yang mengakui prinsip negara hukum sebagaimana halnya di Indonesia.

Efek protektif dan efek jera dari sanksi hukum pidana Indonesia, jika dibandingkan dengan hukum pidana Islam, memerlukan pengkajian secara mendalam dengan menggali asas-asas hukum, norma-norma hukum dan doktrin-doktrin tentang ajaran hukum dari dua sistem hukum pidana tersebut.

\section{B. ANALISIS DAN PEMBAHASAN}

\section{Hakikat Sanksi Dalam Perspektif Hukum Pidana Indonesia}

Istilah sanksi atau hukuman berasal dari kata dasar "hukum" yang berarti menetapkan hukum, atau memutuskan tentang hukum untuk suatu peristiwa yang tidak hanya menyangkut bidang hukum pidana, tetapi juga hukum perdata. ${ }^{3}$ Menurut Achmad Ali bahwa hukum adalah seperangkat kaidah atau ukuran yang tersusun dalam suatu sistem yang menentukan apa yang boleh, dan tidak boleh dilakukan oleh manusia sebagai warga dalam kehidupan bermasyarakatnya. Hukum tersebut bersumber baik dari masyarakat sendiri, maupun dari sumber lain yang diakui berlakunya oleh otoritas tertinggi dalam masyarakat tersebut, serta benar-benar diberlakukan oleh warga masyarakat (sebagai satu keseluruhan) dalam kehidupannya. Jika kaidah tersebut, dilanggar akan memberikan kewenangan bagi otoritas tertinggi untuk menjatuhkan "sanksi" yang sifatnya eksternal. Jadi, unsur-unsur yang harus ada bagi hukum sebagai

\footnotetext{
${ }^{2}$ Ibid.

${ }^{3}$ Sudarto, Kapita Selekta Hukum Pidana, Edisi I, Cet.III, Alumni, Bandung, 2006, hlm. 71-72. P.A.F. Lamintang dan Theo Lamintang, Hukum Penitensier Indonesia, Edisi II, Cet. I, Sinar Grafika, Jakarta, 2010, hlm. 35.
}

Vol. 19 No. 2 November 2017 
kaidah adalah:

1) Harus ada seperangkat kaidah atau aturan yang tersusun dalam satu sistem. Yaitu adanya seperangkat kaidah yang tersusun dalam satu sistem, inilah yang membedakan dengan aturan-aturan yang hidup dalam masyarakat, tetapi tidak tersusun dalam satu sistem, misalnya "aturan" yang berlaku dalam sekelompok perampok. Sistem disini mengandung arti, suatu keseluruhan yang terdiri dari bagian-bagian, dimana antara bagian yang satu dengan yang lain saling berkaitan secara timbal balik, tidak tumpang tindih, dan terjadi pertentangan. Jika terjadi tumpang tindih ataupun pertentangan, maka suatu sistem yang baik mempunyai jalan keluar untuk menyelesaikannya;

2) Perangkat kaidah itu menentukan apa yang boleh dan tidak boleh dilakukan oleh warga masyarakat. Perangkat kaidah itu tentu saja normatif muatannya, yang menentukan apa yang boleh dan tidak boleh dilakukan. Tentang pengertian boleh dan tidak boleh disini mencakup perintah dan larangan;

3) Berlaku bagi manusia sebagai masyarakat dan bukan manusia sebagai individu. Hukum mengatur manusia dan kehidupannya sebagai anggota masyarakat, bukan manusia dalam kehidupan pribadinya sebagai individu. Oleh karena itu, tidak ada aturan hukum yang mengatur bagaimana seyogianya si A mandi di kamar mandi rumahnya sendiri. Namun, yang diatur ialah "manusia", juga "badan hukum" yang dalam kenyataannya dijalankan oleh manusia;

4) Kaidah itu bersumber baik dari masyarakat sendiri maupun dari sumber lain, seperti otoritas negara ataupun dari Tuhan (hukum agama). Sumber dari apa yang menjelma menjadi kaidah hukum, tidak menjadi persoalan. Kaidah hukum bisa bersumber dari undang-undang, kebiasaan, traktat, putusan pengadilan, pendapat pakar (doktrin), hukum agama, dan sebagainya. Yang penting, negara sebagai otoritas tertinggi mengakui eksistensi dan pemberlakuannya dalam masyarakat;

5) Kaidah itu secara nyata benar-benar diberlakukan oleh masyarakat (sebagai satu kesatuan) di dalam kehidupan mereka, yakni living law. Kaidah itu harus secara nyata diterima oleh masyarakat dan masih digunakan sebagai living law. Bukan kaidahkaidah yang hanya tertulis dalam undang-undang, tetapi tidak pernah diberlakukan lagi dan sudah menjadi "hukum mati";

6) Harus ada sanksi eksternal jika terjadi pelanggaran kaidah hukum tersebut, di mana dipertahankan oleh otoritas tertinggi.

Adanya sanksi bagi pelanggar. Sanksi itu bukan bersifat internal, tetapi harus bersifat eksternal, artinya berasal dari luar diri pelakunya, seperti sanksi penjara, dan sanksi itu dilaksanakan dengan wibawa otoritas tertinggi melalui aparatnya. ${ }^{4}$

Sanksi atau hukuman adalah sebuah sinonim dari pemidanaan, atau pemberian penjatuhan pidana oleh hakim. Sanksi/hukuman atau pidana sebagai sebuah istilah dalam hukum pidana menunjukkan sifat-sifat dan ciri-ciri tersendiri, dan banyak sarjana menyebutkan bahwa sifat dan ciri hukuman sebagai sebuah derita atau nestapa yang ditujukan kepada pelaku kejahatan.

Jika hukum dipandang sebagai kaidah, maka tidak boleh tidak, harus diakui sanksi sebagai salah satu unsur esensialnya. Hampir semua yuris yang berpandangan dogmatik

${ }^{4}$ Achmad Ali. Menguak Tabir Hukum, edisi kedua, Ghalia Indonesia, Bogor, 2008, hlm.30-31.

Vol. 19 No. 2 November 2017 
memandang hukum sebagai kaidah bersanksi yang didukung oleh otoritas tertinggi di dalam masyarakatnya. ${ }^{5}$

Menurut Sudikno Mertokusumo bahwa "sanksi tidak lain merupakan reaksi, akibat, atau konsekuensi pelanggaran kaidah sosial”. Berdasarkan beberapa pengertian sanksi tersebut, setidaknya sanksi mengandung unsur-unsur sebagai berikut:

a. Sanksi merupakan reaksi, akibat, atau konsekuensi dari pelanggaran atau penyimpangan kaidah sosial (baik kaidah hukum maupun kaidah non hukum);

b. Sanksi merupakan kekuasaan atau alat kekuasaan untuk memaksakan ditaatinya kaidah sosial tertentu;

C. Khusus mengenai sanksi hukum, pada garis besarnya dapat dibedakan atas:

\section{- Sanksi privat, dan Sanksi publik. ${ }^{6}$}

Dengan demikian, kaidah hukum sebagai salah satu jenis kaidah sosial, jelas membutuhkan unsur sanksi sebagai unsur esensialnya. ${ }^{7}$

Tujuan pidana biasa disingkat dengan tiga $\mathrm{R}$ dan satu $\mathrm{D}$. Tiga $\mathrm{R}$ itu ialah Reformation, Restraint, dan Retribution, sedangkan satu D, ialah Deterrence yang terdiri atas individual deterrence dan general deterrence (pencegahan khusus dan pencegahan umum). Reformation (Reformasi) berarti memperbaiki atau merehabilitasi penjahat menjadi orang baik, dan berguna bagi masyarakat. Masyarakat akan memperoleh keuntungan dan tiada seorang pun yang merugi jika penjahat menjadi baik. Reformasi perlu digabung dengan tujuan yang lain seperti pencegahan. Kritikan terhadap reformasi. ialah ia tidak berhasil. Ketidakberhasilannya nyata banyaknya residivis setelah menjalani pidana penjara. ${ }^{8}$ Yang perlu ditingkatkan dalam sistem reformasi ini, adalah intensitas latihan di penjara lebih ditingkatkan.

Restraint maksudnya mengasingkan pelanggar dari masyarakat. Dengan tersingkirnya pelanggar hukum dari masyarakat berarti masyarakat itu akan menjadi lebih aman. Jadi ada juga kaitannya dengan sistem reformasi, jika dipertanyakan berapa lama terpidana harus diperbaiki di dalam penjara yang bersamaan dengan itu ia tidak berada di tengah-tengah masyarakat. Masyarakat memerlukan perlindungan fisik dari perampok bersenjata dan penodong daripada orang yang melakukan penggelapan.

Retribution, ialah pembalasan terhadap pelanggar karena telah melakukan kejahatan. Sekarang ini, banyak dikritik sebagai sistem yang bersifat barbar dan tidak sesuai dengan masyarakat yang beradab. Namun bagi yang pro pembalasan ini mengatakan, bahwa orang yang menciptakan sistem yang lebih lunak kepada penjahat seperti reformasi itu membuat Magna Carta bagi penjahat (Magna Carta for law breaker). Sifat primitif hukum pidana memang sulit dihilangkan, berbeda dengan bidang hukum yang lain.

Deterence, berarti menjera atau mencegah sehingga baik terdakwa sebagai individual, maupun orang lain yang potensial menjadi penjahat akan jera atau takut untuk melakukan kejahatan, melihat pidana yang dijatuhkan kepada terdakwa. Yang

${ }^{5}$ Achmad Ali. Menguak Tabir Hukum, edisi kedua, Ghalia Indonesia, Bogor, 2008, hlm.30-31.

${ }^{6}$ Ibid.

${ }^{7}$ Ibid.

${ }^{8}$ A. Hamzah. Asas-Asas Hukum Pidana. Ed. Revisi, Rineke Cipta, Jakarta, 2008, hlm. 28. Vol. 19 No. 2 November 2017 
mengkritik teori ini mengatakan, adalah kurang adil jika untuk tujuan mencegah orang lain melakukan kejahatan terpidana dikorbankan untuk menerima pidana itu.

Teori tentang tujuan pidana memang semakin hari semakin menuju ke arah sistem yang lebih manusiawi dan lebih rasional. Perjalanan sistem pidana menunjukkan bahwa retribution (revenge), atau untuk tujuan memuaskan pihak yang dendam baik masyarakat sendiri, maupun pihak yang dirugikan atau menjadi korban kejahatan. Hal ini bersifat primitif, tetapi kadang-kadang masih terasa pengaruhnya pada zaman modern ini. Juga dipandang kuno ialah penghapusan dosa (expiation), yaitu melepaskan pelanggar hukum dari perbuatan jahat atau menciptakan balans antara yang hak dan yang batil.

Tujuan pidana yang berlaku sekarang, ialah variasi dari bentuk-bentuk: penjeraan (deterrent), baik ditujukan kepada pelanggar hukum sendiri, maupun kepada mereka yang mempunyai potensi menjadi penjahat; perlindungan kepada masyarakat dari perbuatan jahat; perbaikan (reformasi) kepada penjahat. Yang tersebut terakhir yang paling modern dan populer dewasa ini. Bukan saja bertujuan memperbaiki kondisi pemenjaraan, tetapi juga mencari alternatif lain yang bukan bersifat pidana dalam membina pelanggar hukum. ${ }^{9}$

Berpijak pada tujuan pidana tersebut, muncullah teori-teori tentang pemidanaan. Ada (3) tiga golongan utama teori untuk membenarkan penjatuhan pidana :

1) Teori absolut teori pembalasan (vergeldings theorien).

2) Teori relatif atau tujuan (doeltheorien).

3) Teori gabungan (verenigingstheorien).

Teori pertama muncul pada akhir abad ke 18, dianut antara lain oleh Immanuel Kant, Hegel, Herbart, Stahl, Leo Polak dan beberapa sarjana yang mendasarkan teorinya pada filsafat Katolik dan sudah sepatutnya, sarjana hukum Islam mendasarkan teorinya pada ajaran kisas dalam Al-Qur'an.

Teori pembalasan menyatakan bahwa pidana tidaklah bertujuan untuk yang praktis, seperti memperbaiki penjahat. Kejahatan itu sendirilah yang mengandung unsur-unsur untuk dijatuhkannya pidana. Pidana secara mutlak ada, karena dilakukan suatu kejahatan. Tidaklah perlu untuk memikirkan manfaat menjatuhkan pidana itu. Setiap kejahatan harus berakibat dijatuhkan pidana kepada pelanggar. Karena itu, maka teori ini disebut teori absolut. Pidana merupakan tuntutan mutlak, bukan hanya sesuatu yang perlu dijatuhkan, tetapi menjadi keharusan. Hakikat suatu pidana ialah pembalasan. Teori kedua, yaitu teori relatif atau teori tujuan, yang berpangkal pada dasar bahwa pidana, adalah alat untuk menegakkan ketertiban (hukum) dalam masyarakat. Jadi, pada dasarnya tujuan pemidanaan adalah untuk mencegah, atau prevensi terjadinya pelanggaran atau kejahatan. Wujud pemidanaan menurut teori ini berbeda- beda, yaitu menakut-nakuti (afschrikking), memperbaiki (verbetering/reclasering), atau membinasakan (onshadelijk maken). Adapun sifat pencegahannya dibedakan menjadi prevensi umum dan khusus.

Prevensi umum menghendaki agar orang-orang pada umumnya tidak melakukan delik, sehingga eksekusinya dilakukan di depan umum sebagaimana dikemukakan oleh

${ }^{9}$ ibid, hal, 29

Vol. 19 No. 2 November 2017 
teori von Feurbach. Namun teori ini, dibantah oleh teori Muller yang menyatakan bahwa akibat preventif itu bukan terletak pada eksekusi pidana maupun dalam ancaman pidana, tetapi pada penentuan pidana secara konkret oleh hakim.

Prevensi khusus yang dianut oleh van Hamel (Belanda) dan von Lizst (Jerman) menyatakan bahwa tujuan prevensi khusus, ialah mencegah niat buruk pelaku (dader) mengulangi perbuatannya, atau mencegah bakal pelanggar melaksanakan perbuatan jahat yang direncanakannya. Menurut van Hamel (Belanda), prevensi khusus suatu pidana, ialah:

a) Pidana harus memuat suatu unsur menakutkan supaya mencegah penjahat yang mempunyai kesempatan untuk tidak melaksanakan niat buruknya;

b) Pidana harus mempunyai unsur memperbaiki terpidana;

c) Pidana mempunyai unsur membinasakan penjahat yang tidak mungkin diperbaiki;

d) Tujuan satu-satunya suatu pidana, ialah mempertahankan tata tertib hukum.

Teori ketiga, ialah teori gabungan antara teori pembalasan dan teori tujuan. Teori ini, ada yang menitikberatkan pada pembalasan dan ada pula yang menginginkan unsur pembalasan dan prevensi seimbang, sebagaimana uraian berikut:

a) Teori gabungan pertama menitikberatkan unsur pembalasan sebagaimana dianut oleh Pompe dengan menyatakan:

"Orang tidak boleh menutup mata pada pembalasan. Memang pidana dapat dibedakan dengan sanksi-sanksi lain, tetapi tetap ada ciri-cirinya. Tetap tidak dapat dikecilkan artinya bahwa pidana adalah suatu sanksi, dan dengan demikian terikat dengan tujuan sanksi-sanksi itu. Dan karena itu, hanya akan diterapkan jika menguntungkan pemenuhan kaidah-kaidah dan berguna bagi kepentingan umum".

b) Teori gabungan kedua, yaitu menitikberatkan pada ketahanan tata tertib masyarakat. Teori ini menyatakan bahwa penjatuhan pidana tidak boleh lebih berat daripada yang ditimbulkannya, dan gunanya juga tidak boleh lebih besar daripada yang seharusnya. Teori ini sejajar dengan teori Thomas Aquino yang menyatakan bahwa kesejahteraan umum merupakan dasar hukum undang-undang pidana. Sebab tujuan pemidanaan, ialah melindungi kesejahteraan masyarakat.

c) Teori gabungan ketiga memandang sama pembalasan dan ketahanan tertib masyarakat. Namun demikian, teori Ini kurang dibahas oleh para sarjana.

Dalam Rancangan KUHP nasional, telah diatur tentang tujuan penjatuhan pidana, yaitu :

1) Mencegah dilakukannya tindak pidana dengan menegakkan norma hukum demi pengayoman masyarakat;

2) Mengadakan koreksi terhadap terpidana dan dengan demikian menjadikannya orang yang baik dan berguna;

3) Menyelesaikan konflik yang ditimbulkan oleh tindak pidana, memulihkan keseimbangan dan mendatangkan rasa damai dalam masyarakat;

4) Membebaskan rasa bersalah pada terpidana (Pasal 5).

Dalam ayat 2 pasal itu, ditegaskan bahwa pemidanaan tidak dimaksudkan untuk 
menderitakan dan tidak diperkenankan merendahkan martabat manusia. Dengan demikian dapat dikatakan bahwa yang tercantum di dalam rancangan KUHP tersebut, merupakan penjabaran teori gabungan dalam arti yang luas. Ia meliputi usaha prevensi, koreksi kedamaian dalam masyarakat dan pembebasan rasa bersalah pada terpidana (mirip dengan expiation).

\section{Hakikat Sanksi Dalam Perspektif Hukum Pidana Islam}

Sanksi adalah Hukuman yang telah ditentukan untuk kemaslahatan masyarakat, karena melanggar perintah syar'i (Allah SWT dan rasul-Nya). Tujuan dijatuhkannya hukuman, adalah untuk memperbaiki keadaan manusia, menjaga dari kerusakan, menyelamatkan dari kebodohan, menuntun dan memberikan petunjuk dari kesesatan, mencegah dari kemaksiatan, serta merangsang untuk berlaku taat. Allah SWT tidak mengutus rasul-Nya untuk menguasai dan memaksa manusia, tetapi sebagai rahmat bagi semesta alam. Hal ini ditegaskan dalam firman Allah SWT, QS. Al-Gasyiyah (88 ): 22 yang artinya : "Kamu bukanlah orang yang berkuasa atas mereka.

Selain itu, dalam firman Allah SWT, QS. Qaf: (50) : 45 yang artinya : "Kami lebih mengetahui tentang apa yang mereka katakan, dan kamu sekali-kali bukanlah seorang pemaksa terhadap mereka. Maka beri peringatanlah dengan Al Qur'an orang yang takut dengan ancaman-Ku".

Demikian pula dalam firman Allah SWT, QS. al-Anbiya' (21) : 107) yang artinya : "Dan tiadalah kami mengutus kamu, melainkan untuk (menjadi) rahmat bagi semesta alam".

Allah SWT menurunkan syariat-Nya dan mengutus para rasul-Nya untuk mengajari dan memberikan petunjuk bagi manusia. Ia telah menetapkan hukuman bagi yang melanggar perintah-Nya, untuk mendorong manusia ke arah yang tidak mereka sukai selama hal itu dapat mewujudkan kemaslahatan mereka, dan memalingkan dari keinginannya selama hal itu dapat mengakibatkan kerusakan pada dirinya.

Hukuman ditetapkan untuk memperbaiki dan mengajari individu (islah), menjaga masyarakat umum, dan memelihara sistem mereka. Allah-lah yang mensyariatkan hukuman ini, dan memerintahkannya kepada manusia. Allah tidak dirugikan oleh kemaksiatan manusia, walaupun seluruh manusia di bumi bermaksiat kepada-Nya. Begitu juga, Allah SWT tidak diuntungkan oleh ketaatan manusia, walaupun semua manusia mematuhi-Nya.

Salah satu dari ketentuan hukum Islam, adalah hukum pidana Islam. Namun, selama ini banyak kalangan yang menganggap bahwa hukum pidana Islam, adalah hukum yang kejam, tidak manusiawi, dan tidak menghormati hak-hak asasi manusia.

Sebagaimana yang telah diketahui bahwa salah satu sumber hukum pidana Islam, adalah Al-Qur'an dan yang menciptakan Al-Qur'an adalah Allah SWT, bukan manusia. Karenanya, jangan pernah mengatakan bahwa hukum pidana Islam itu kejam dan tidak manusiawi, sebab secara tidak sadar kita telah mengatakan bahwa Allah itu kejam dan tidak manusiawi.

Teori pemidanaan dalam hukum pidana Islam ini, dapat diketahui dari tujuan dijatuhkannya pidana, yang dapat dirumuskan dari tujuan masing-masing pidana dalam hukum pidana Islam, yaitu tujuan hudud, kisas-diat dan takzir. Sedangkan dalam hukum

Vol. 19 No. 2 November 2017 
pidana Indonesia, teori pemidanaan ini terdiri dari tiga teori, yaitu teori absolut, teori relatif dan teori gabungan.

Perbedaan tujuan pemidanaan dalam hukum pidana Islam dan hukum pidana Indonesia, yaitu :

1) Teori pembalasan yang terdapat dalam hukum pidana Islam dikenal adanya afwa/pemaafan, sedangkan dalam hukum pidana Indonesia tidak dikenal.

2) Teori relatif/tujuan yang terdapat dalam hukum pidana Islam lebih tegas dibandingkan dalam hukum pidana Indonesia.

3) Prinsip dasar pelaksanaan dari penjatuhan pidana dalam hukum pidana Islam merupakan wujud ketaatan seorang hamba kepada Allah SWT yang didasari keimanan, sedangkan dalam hukum pidana Indonesia, prinsip dasar pelaksanaan penjatuhan pidana, karena semata-mata taat pada aturan yang dibuat oleh manusia, yang belum tentu baik dan benar.

Berdasarkan perbedaan tujuan pemidanaan dalam hukum pidana Islam dan hukum pidana Indonesia tersebut, maka dapat dikatakan bahwa hakikat sanksi dalam perspektif hukum pidana Islam yang sebenarnya (sesungguhnya), adalah untuk menjaga/memelihara kemaslahatan individu, dan masyarakat dengan tidak mengorbankan hak masyarakat demi mewujudkan hak individu. Sedangkan hakikat sanksi dalam hukum pidana Indonsia semata-mata hanya menjaga/memelihara kemaslahatan individu.

Hukuman yang lebih mengutamakan kemaslahatan perseorangan atas kemaslahatan masyarakat, sebenarnya justru menghilangkan kemaslahatan individu dan masyarakat, sehingga akan mendorong bertambahnya jumlah tindak pidana, rusaknya keamanan, melemahkan sistem dan memecah belah masyarakat. Apabila perpecahan ini, semakin menyebar, maka semakin berkuranglah rasa kepercayaan antara sesama manusia (masyarakat).

\section{Hakikat Pidana Mati}

Keberadaan pidana mati sebagai salah satu sanksi, sebenarnya bukan hanya berlaku di Indonesia, tetapi juga berlaku di berbagai negara. Bahkan di negara-negara yang selama ini gigih memperjuangkan perlindungan terhadap hak asasi manusia, seperti Amerika Serikat (AS), juga tidak menghapuskan secara penuh keberadaan pidana mati. Pada tahun 1976 Mahkamah Agung (MA) AS menyatakan pidana mati bukan merupakan suatu "pidana yang kejam dan tidak biasa" (cruel and unusual punishment). Terhadap jenis tindak pidana tertentu, seperti pembunuhan berencana, pidana mati tetap diberlakukan sebagai salah satu jenis pidana pokok. Hal ini menunjukkan, walaupun penerapan pidana mati banyak ditentang oleh berbagai kalangan, tetapi banyak juga negara yang masih menginginkan pidana mati tetap diberlakukan, khususnya untuk delik-delik tertentu, termasuk di negara-negara liberal yang merupakan tempat awal mula munculnya pemikiran tentang HAM.

Para ahli yang setuju penerapan pidana mati pada umumnya mendasarkan pandangannya pada teori utilitarianisme dan teori retributivisme. Sementara yang menolak penerapan pidana mati, pada umumnya mendasarkan pandangannya dengan merujuk pada teori abolisionisme. Dalam pandangan utilitarianisme, pembenaran sanksi terletak pada manfaatnya yang menguntungkan bagi sebanyak mungkin orang. Dengan 
merujuk pada pandangan tersebut, maka penerapan pidana mati merupakan sarana penjeraan dan penangkalan yang paling efektif dan efisien. Pelaksanaan pidana mati ditangan algojo, sebagai suatu hal yang buruk dan mengerikan, diharapkan dapat menimbulkan ketakutan bagi setiap anggota masyarakat, sehingga mampu memberikan manfaat dengan munculnya efek jera (deterrent effect), dan daya tangkal (prevency effect) bagi mayoritas orang. Untuk itu, maka eksekusi mati pada masa lalu dilakukan di tempat terbuka, dan disaksikan oleh masyarakat agar efek maksimumnya dapat dicapai.

Efektivitas pidana mati sebagai alat penjeraan dan penangkalan ternyata diragukan oleh Cesare Beccaria (1738-1794). Menurutnya, pidana mati bukanlah jenis penjeraan dan penangkalan yang efektif, karena suatu eksekusi publik tidak menghasilkan kesan yang kuat dalam perasaan warga masyarakat. Sebab perasaan seseorang secara lebih mudah dan menetap dipengaruhi oleh kesan-kesan yang ringan tetapi diulang-ulang daripada tindakan-tindakan dahsyat tetapi hanya seketika. Bukan tontotan kematian seorang penjahat secara mengerikan dan seketika, tetapi contoh penderitaan yang lama dari seseorang yang dilucuti kebebasannya, menjadi binatang tunggangan, atau kerja paksa bagi kepentingan masyarakat yang dilukainya, merupakan kendali yang paling kuat terhadap kejahatan-kejahatan. Dengan kata lain, efektivitas penjeraan terletak pada durasi penderitaan akibat suatu sanksi. Karena itu, Beccaria lebih menyetujui pidana penjara seumur hidup sebagai sarana penjeraan dan penangkalan daripada pidana mati.

Pandangan Beccaria tersebut, ditolak oleh Jeremy Bentham. Bentham membedakan secara sosiologis dua kelas masyarakat. Pertama, mayoritas warga masyarakat yang menghargai kehidupan. Mereka ini takut kematian dan tidak menyukai kejahatan yang diancam pidana mati. Kelompok masyarakat ini jelas membutuhkan sanksi sebagai alat penjeraan atau penangkalan. Kedua, "kelas kriminal" yang posisi sosial dan jalan hidupnya tidak cukup menghargai kehidupan, dan sama sekali tidak takut kehilangan hidupnya. Bagi "kelas kriminal", suatu eksekusi mati sama sekali tidak sengeri seperti bagi mayoritas masyarakat. Pidana mati hanyalah suatu penghentian yang lebih cepat terhadap kehidupan yang tidak mudah, tidak bahagia, dan eksistensi yang tidak terhorrmat. Penghentian kehidupan secara radikal inilah, yang menurut Bentham diharapkan dapat memainkan peran penjeraan dan penangkalan.

Dukungan paling kuat terhadap penerapan pidana mati dari perspektif utilitarianisme datang dari John Stuart Mill. Dalam pidato yang disampaikan pada debat di Parlemen Inggris Tahun 1868, Mill mengemukakan argumen, untuk delik pembunuhan yang serius, eksekusi mati kadang-kadang merupakan sanksi yang paling patut dan yang paling manusiawi. kata "kadang-kadang" digunakan karena tidak semua pembunuh harus di pidana mati, tetapi hanya mereka yang terbukti melakukan pembunuhan secara brutal dan keji (aggravated murder) yang patut dipidana mati. Mill mengemukakan dua alasan dasar mengapa pidana mati diperlukan. Pertama, seorang penjahat memang seharusnya mendapatkan sanksi; dan kedua, pidana mati merupakan sarana penjeraan dan penangkalan yang membawa efek positif bagi keamanan masyarakat. Pidato Mill memiliki pengaruh yang cukup luas dan ketika tahun 1982 diadakan debat terbuka tentang rancangan undang-undang kriminal yang bermaksud mengintroduksi kembali pidana mati untuk kasus-kasus tertentu, argumen-argumen yang dikemukakan Mill diangkat kembali.

Argumentasi Mill bahwa pidana mati merupakan sarana penjeraan dan penangkalan, mendapatkan kritikan dari anggota parlemen Inggris. Sebab berdasarkan pengalaman

Vol. 19 No. 2 November 2017 
ketika pidana mati diterapkan di Inggris pada abad ke-15 untuk hampir semua jenis tindak pidana, ternyata hal itu tidak membangkitkan rasa takut. Saat itu, pidana mati mengancam lebih dari 220 tindak kejahatan, termasuk menebang sebatang pohon di taman umum, merusak empang (fishpond), dan juga bagi para pencopet. Namun ancaman tersebut tidak efektif, walaupun pada awalnya memang mampu menurunkan tingkat kejahatan. Sebab pada abad ke-15 tercatat ada 17 terpidana yang dieksekusi mati, namun pada abad ke-18 kejahatan kembali meningkat, sehingga terjadi lebih dari 200 pidana mati. Di sisi lain, pelaksanaan pidana mati yang dilakukan secara publik, justru menjadi saat panen yang paling menguntungkan bagi para pencopet. Pada saat semua mata dan perhatian tertuju ke tiang gantungan, para pencopet beraksi menggerayangi tas dan saku-saku penonton. Fakta tersebut, membuktikan bahwa pidana mati tidak efektif sebagai alat penjeraan dan penangkalan.

Menyikapi hal tersebut, Mill menyatakan bahwa pengaruh pidana mati tidak dapat diukur dari efeknya atas penjahat yang keji. Sebab mereka yang pada dasarnya sudah jahat, dan sepanjang waktu berada dalam incaran tiang gantungan tentu tidak peduli terhadap efek penjeraan. Sasaran pidana mati sebagai sarana penjeraan adalah masyarakat yang tidak bersalah. Pengertian masyarakat yang tidak bersalah, mencakup pula pengertian, seseorang tidak pernah giat melaksanakan suatu kejahatan. Pidana mati juga gagal sebagai sarana penjeraan, karena pencuri saat itu tidak percaya, ia dapat dikenai pidana mati. Sebab berdasarkan pengalaman para juri cenderung bersumpah palsu daripada berusaha membuktikan kesalahannya. Hakim cenderung memaafkan, sehingga mereka tidak akan menjatuhkan pidana mati, bahkan merekomendasikan belas kasihan dan pengampunan. Ancaman pidana mati bagi para pencuri di Inggris sepanjang paruh kedua abad ke-19, memang gagal menjerakan karena ancaman itu kosong belaka. Demikian pula, bila hal ini diberlakukan terhadap tindak pidana serius seperti pembunuhan, bila pidana mati tersebut hanya sebatas ancaman kosong, dalam arti ada ketentuannya, tetapi tidak pernah diterapkan oleh hakim, maka hal itu juga tidak akan dapat menimbulkan efek jera.

Dukungan terhadap pemberlakuan pidana mati juga datang dari penganut teori retributivisme. Penganut teori ini, menganggap bahwa penjatuhan pidana memiliki landasan moral yang kuat bila mampu memberikan keadilan. Seorang yang terbukti bersalah layak dihukum, adalah sesuatu yang adil dan dapat dibenarkan. Keadilan juga berarti sanksi yang dijatuhkan harus seimbang dengan tingkat kesalahan yang dilakukan. Penganut retributivisme menganggap pidana mati sebagai pidana yang seimbang dan karena itu patut dijatuhkan, jika tindak pidananya adalah pembunuhan yang dilakukan secara terencana. Aliran retributivisme mewajibkan penerapan secara literal lex talionis dalam rangka memberikan perlindungan terhadap harkat dan martabat serta nilai hidup manusia yang begitu luhur.

Ajaran lex talionis sudah lama terdapat dalam agama-agama samawi, seperti Kristen dan Islam. Memang ada ahli yang menyatakan pidana mati tidak sesuai dengan ajaran kristiani yang menekankan cinta kasih. Namun hal ini dapat dibantah dengan adanya beberapa ketentuan dalam Kitab Perjanjian Lama yang mengakui pidana mati. Bahkan Katekismus Gereja Katolik mengakui bahwa pidana mati merupakan bagian dari "ajaran turun-temurun Gereja" sebagaimana dapat dibuktikan dalam Kitab Suci Perjanjian Lama. Misalnya, dalam keluaran 21:12,14, dikatakan bahwa "siapa yang memukul seseorang, sehingga mati, pastilah ia dihukum mati. Apabila seseorang berlaku angkara terhadap Vol. 19 No. 2 November 2017 
sesamanya, hingga ia membunuhnya dengan tipu daya, maka engkau harus mengambil orang itu dari mezbah-Ku, supaya ia mati dibunuh". Hal yang sama juga terdapat dalam Kejadian 9:6 yang menyatakan "siapa yang menumpahkan darah manusia, darahnya akan tertumpah oleh manusia, sebab Allah membuat manusia itu menurut gambar-Nya sendiri. Berdasarkan dua ketentuan tersebut, ajaran kristiani menganggap harkat, martabat dan nilai hidup sedemikian luhur dan tinggi, sehingga tidak terukurkan dan tidak dapat dibandingkan (incommersurable) dengan nilai, atau sesuatu yang lain kecuali hidup manusia itu sendiri. Karena itu, hanya ada satu pidana yang adil dan patut bagi seorang pembunuh, yaitu pencabutan hidupnya melalui eksekusi mati.

Sementara itu, dalam agama Islam ajaran lex talionis juga terdapat dalam Kitab suci Al-Qur'an. Hanya saja ada perbedaan dengan ketentuan yang diatur dalam Kitab Perjanjian Lama. Dalam Kitab Perjanjian Lama keluarga korban tidak boleh meminta tebusan untuk menghapuskan pidana mati bagi seorang pembunuh. Sedangkan dalam Kitab Suci Al-Qur'an, keluarga korban dapat meminta tebusan dan memberi maaf kepada si pembunuh. Ketentuan tersebut diatur dalam surah al-Baqarah (2) : 178) yang artinya:

"Hai orang-orang yang beriman, diwajibkan atas kamu kisas berkenaan dengan orang-orang yang dibunuh; orang merdeka dengan orang merdeka; hamba dengan hamba; dan wanita dengan wanita. Maka barangsiapa yang mendapatkan pema'afan dari saudaranya, hendaklah (yang mema'afkan) mengikuti dengan cara yang baik, dan hendaklah (yang diberi maaf) membayar (diat) kepada yang memberi maaf dengan cara yang baik (pula). Yang demikian itu, adalah sesuatu keringanan dari Tuhan Kamu dan suatu rahmat. Barangsiapa yang melampaui batas sesudah itu, maka baginya siksa yang sangat pedih".

Ketentuan tersebut, mengatur tentang kisas (mengambil pembalasan yang sama) bagi seorang pembunuh. Namun, kisas tidak dilakukan bila yang membunuh mendapatkan ampunan dari ahli waris korban dengan syarat pelaku membayar ganti rugi (diat) yang wajar. Pembayaran diat harus diminta dengan baik, misalnya dengan tidak mendesak yang membunuh. Sang pembunuh juga harus membayarnya dengan baik, misalnya tidak menangguh-nangguhkan. Sesudah Allah SWT menjelaskan hukum- hukum ini, bila ahli waris korban membunuh si pembunuh setelah menerima diat, maka terhadapnya di dunia diambil kisas dan di akhirat mendapatkan siksa yang pedih.

Menurut ajaran Islam di dalam kisas terdapat jaminan kelangsungan hidup bagi umat manusia. Hal ini secara tegas dinyatakan dalam surah Al-Baqarah (2) ayat 179 yang artinya:

"Di dalam hukum kisas itu ada jaminan kelangsungan hidup bagimu hai orangorang yang berakal, supaya kamu bertakwa".

Hal ini berarti, penerapan hukum kisas khususnya kepada pelaku pembunuhan, pada hakikatnya dimaksudkan untuk memberikan perlindungan terhadap harkat dan martabat manusia serta nilai kehidupan yang luhur, yang diberikan Tuhan Yang Maha Kuasa kepada setiap manusia. Dengan adanya hukum kisas, diharapkan setiap orang tidak dengan mudah melakukan pembunuhan, atau menghilangkan nyawa orang lain. Sebab perbuatan seperti itu, dapat membawa akibat bagi dihilangkannya nyawanya sendiri.

Penolakan terhadap penerapan pidana mati dikemukakan oleh kaum abilisionis, yang didasarkan pada beberapa argumen, yaitu:

Vol. 19 No. 2 November 2017 
1) Merujuk pada dua argumen Beccaria; pertama, pidana mati dilihat dari ilmu psikologi tidak menimbulkan kesan yang mendalam dan lama pada masyarakat sehingga efek penjeraan tidak efektif. Beccaria mengusulkan pidana penjara seumur hidup sebagai alternatifnya. Argumen ini sudah dibantah oleh Bentham, Mill. Kedua, dilihat dari ilmu politik, negara tidak memiliki hak untuk mencabut hak hidup seseorang, karena dalam kontrak sosial pembentukan negara individu tidak menyerahkan kepada negara hak untuk mencabut hidup warga negaranya dalam keadaan tertentu. Namun hal ini dikritik oleh Hegel, karena menurut Hegel negara bukanlah suatu kontrak sosial. Negara adalah institusi yang lebih tinggi, karena merupakan sintetis antara keluarga sebagai tesis dan masyarakat sipil (civil society) sebagai antithesis. Dalam suatu negara, kepentingan individu dan kepentingan bersama, sama-sama dilindungi, sehingga apabila ada individu atau lembaga kemudian merusak general will yang dilindungi oleh hukum, maka sebagai lembaga tinggi, negara berhak dan berkewajiban menghukum si pelanggar.

2) Pidana mati tidak dapat dibenarkan, karena bertentangan dengan hak untuk hidup, yaitu suatu hak yang fundamental, absolut dan luhur yang dimiliki oleh setiap manusia, dan karena itu harus dihargai bahkan pada seorang pembunuh sekalipun. Hak untuk hidup merupakan hak yang fundamental, namun bila dianggap sebagai sesuatu yang absolut tentu sulit untuk diterima. Bagaimana bila terjadi peperangan, revolusi maupun pembelaan diri, bila seseorang tidak mempertahankan diri dengan melakukan pembunuhan tentu dia akan dibunuh. Bila hak ini dianggap absolut, justru akan dijadikan tameng bagi pembunuh untuk menghindari pidana mati. Padahal sebenarnya dia telah melanggar hak absolut tersebut, dengan melakukan pembunuhan.

3) Argumen ini ditujukan untuk melawan prinsip proporsionalitas yang dianut kaum retributif, yang menyatakan bahwa pidana bagi pembunuh dinilai adil dan patut, karena setiap manusia (baik korban maupun pelaku) memiliki nilai yang sama. Namun menurut abilisionis, kehidupan dua orang dapat sama sekali berbeda menurut berbagai faktor penting, seperti: umur, kondisi tubuh, status sosial, atau kemampuan psikologis. Untuk itu, kesamaan nilai yang dikemukakan kaum retributif harus mengenal batasan, sehingga proporsionalitas dalam kasus pembunuhan tidak berarti harus ada pidana mati. Bila merujuk argumen ini, pidana mati sebenarnya tidak dihapus sama sekali, karena argumen tersebut hanya mengatakan tidak harus ada pidana mati, sehingga dapat juga diartikan dalam kondisi tertentu dapat pula diadakan.

4) Argumen ini merupakan argumen yang paling fundamental dari kaum abilisionis dalam melawan pidana mati. Argumen ini didasarkan atas keyakinan tentang keluhuran atau kesucian hidup (the sanctity of life), yang dipahami dari berbagai pengertian. Pertama, hidup itu berasal dari Tuhan sang Pencipta dan karena itu luhur sifatnya, sehingga manusia tidak berhak mencabutnya; Kedua, keluhuran hidup dimengerti sebagai hak untuk hidup dan hak atas kehidupan yang dilindungi; Ketiga, keluhuran hidup berarti adanya muatan nilai yang bermakna intrinsik, tidak terbatas, tidak terbandingkan, dan karena itu mutlak hakikatnya. Kaum beragama biasanya menggunakan pengertian pertama untuk menolak pidana mati; pengertian kedua digunakan oleh kaum humanis sekuler, dan pengertian ketiga digunakan dari sisi etika. Namun sebaliknya, keluhuran atau kesucian hidup justru digunakan penganut aliran retributif untuk menerapkan pidana mati. Berpijak pada landasan tersebut, kaum retributif berpendapat bahwa 
keluhuran atau kesucian hidup merupakan landasan utama tidak diperbolehkannya seseorang mencabut nyawa orang lain. Untuk itu, seseorang yang menghilangkan hak hidup orang lain, balasan yang setimpal ialah hak hidupnya juga harus dihilangkan.

Dewasa ini, argumentasi terkait pro-kontra pidana mati berkembang dengan merujuk pada instrumen HAM. Menurut mereka yang menolak penerapan pidana mati, hak hidup merupakan salah satu hak asasi manusia yang tidak dapat dikurangi sedikitpun dalam keadaan apapun (non derogble rights). Pandangan tersebut didasarkan pada Pasal 4 ayat (2) International Covenant on Civil and Political Rights (ICCPR), yang menyatakan "pengurangan kewajiban atas Pasal-Pasal 6, 7, 8 ayat (1) dan (2), 11, 15, 16 dan 18 sama sekali tidak dapat dibenarkan berdasarkan ketentuan ini". Salah satu hak asasi yang masuk dalam kategori non derogable rights, ialah hak untuk hidup sebagaimana diatur dalam Pasal 6 ayat (1) ICCPR. Namun menurut Pasal 6 ayat (2) ICCPR, pidana mati tetap diperbolehkan untuk kejahatan paling serius. Bahkan dalam konvenan tersebut tidak diatur secara tegas, jenis-jenis kejahatan yang dapat dikategorikan sebagai "kejahatan paling serius". Pasal 6 ayat (2) ICCPR membiarkan the most serious crime terbuka dan menjadi kewenangan masing-masing negara untuk menentukan jenis kejahatan yang dianggap sebagai kejahatan yang paling serius di negara yang bersangkutan.

Dalam konteks Indonesia, hak asasi manusia yang masuk dalam kategori non derogable rights, namun UUD NRI Tahun 1945 juga mengatur pembatasan hak dan kebebasan asasi sebagaimana diatur Pasal 28J ayat (2). Bahkan dalam Pasal 28J ayat (2) tidak ada pengecualian pembatasan untuk hak-hak yang diatur dalam Pasal 28I ayat (1). Hal ini menunjukkan, walaupun hak untuk hidup masuk dalam kategori non derogable rights, namun tetap dapat dibatasi dan wajib tunduk kepada pembatasan yang ditetapkan oleh undang-undang.

Pembatasan terhadap hak dan kebebasan asasi, bukan hanya diatur dalam instrumen hukum nasional, tetapi juga diatur dalam instrumen hukum internasional. Pasal 29 ayat (2) The Universal Declaration of Human Rights (UDHR) menekankan adanya batasanbatasan yang ditentukan oleh hukum, bagi berlakunya hak dan kebebasan asasi manusia. Pembatasan tersebut, semata-mata diperlukan untuk menjamin pengakuan dan penghormatan terhadap hak dan kebebasan orang lain, dan memenuhi persyaratanpersyaratan moral, ketertiban umum dan kesejahteraan umum yang adil dalam masyarakat yang demokratis. Hal ini berarti baik instrumen nasional maupun instrumen internasional sama-sama mengenal adanya pembatasan terhadap hak dan kebebasan asasi.

Selanjutnya di dalam Pasal 29 ayat (3) UDHR disebutkan bahwa hak dan kebebasan asasi manusia dengan jalan apapun tidak dapat dilaksanakan bila bertentangan dengan tujuan dan prinsip-prinsip PBB. Hal ini berarti, walaupun hak untuk hidup tersebut merupakan hak yang fundamental, namun apabila hak untuk hidup tersebut digunakan untuk menghilangkan hak hidup orang lain, maka hak untuk hidup tersebut tidak dapat dijalankan. Sebab hal yang demikian itu, bertentangan dengan tujuan dan prinsip PBB, menjamin pengakuan dan penghormatan terhadap hak dan kebebasan orang lain.

Dalam berbagai instrumen di atas (baik instrumen internasional maupun nasional), sangat jelas ada ketentuan yang membatasi semua hak asasi, baik yang masuk dalam kategori non derogable rights maupun derogable rights. Dalam UDHR, pembatasan tersebut terdapat dalam Pasal 29 dan dalam Pasal 28J ayat (2) UUD NRI Tahun 1945.

Vol. 19 No. 2 November 2017 
Pengecualian terhadap hak hidup, juga terdapat dalam Pasal 6 ayat (2) ICCPR. Dengan demikian, maka penerapan pidana mati, pada hakikatnya tidak bertentangan dengan prinsip-prinsip HAM, baik menurut instrumen nasional maupun internasional, dan pada hakikatnya penerapan pidana mati, adalah untuk melindungi harkat dan martabat serta hak hidup manusia yang sangat luhur, baik secara individu maupun masyarakat secara keseluruhan. Negara wajib melindungi Hak hidup yang dimiliki oleh banyak orang, dibandingkan melindungi hak hidup seorang penjahat yang tega menghabisi nyawa orang secara kejam dan sadis. Seseorang yang melakukan kejahatan sampai dijatuhi pidana mati, pada hakikatnya dalam dirinya sudah hilang rasa kemanusiaan, sehingga ancaman pidana mati sebagaimana yang dikemukakan oleh Bentham, tidak akan mampu sebagai sarana penjeraan, dan oleh karenanya penjahat seperti itu harus dilenyapkan dari muka bumi, sebab orang seperti itu sangat berbahaya dan akan mempengaruhi, mengajak bahkan mengajarkan ilmu kejahatan pada orang lain dan hal ini dapat berlangsung secara turun temurun.

Secara jelas dan tegas disampaikan dalam Al-Qur'an dan hadis Rasulullah Saw, sebagaimana firman Allah SWT dalam Surah Al-Baqarah (2) ayat 179 yang menyatakan bahwa diberlakukannya hukum kisas dalam pembunuhan adalah demi terjaganya kelangsungan hidup. Dalam hukum kisas juga terkandung prinsip utama dari hak asasi manusia, yaitu "persamaan". Oleh karena itu, pembunuhan harus dibayar dengan hal yang sama yaitu dihilangkannya nyawa pelaku. Adapun hadis Rasulullah Saw sebagai berikut:

“Abu Qatadah bin Robi' ra. menceritakan, suatu ketika ada jenazah yang lewat dihadapan Nabi SAW, lalu beliau bersabda, "Senang dan Menyenangkan".

“Apa maksud ucapan engkau itu, ya Rasulullah?” tanya para sahabat. Muhammad Rasulullah Saw bersabda, "Apabila seorang mukmin meninggal dunia, maka dia telah senang (istirahat) dari kesusahan dunia. Dan jika seorang jahat yang meninggal, maka dia menyenangkan seluruh hamba Allah, seluruh negeri, seluruh pohon-pohon, dan binatang dari kejahatannya". (HR.Muslim).

Kitab Suci Al-Qur'an bagi umat Islam, merupakan ketentuan Tuhan yang tidak dapat diragukan lagi kebenarannya sebagaimana firman Allah SWT dalam surah AlBaqarah (2) ayat 2, yang artinya, "Kitab (Al-Qur'an) ini tidak ada keraguan padanya; petunjuk bagi mereka yang bertakwa". Oleh karena itu, hukum-hukum yang terdapat dalam Al-Qur'an merupakan hukum suci (divine law atau lex divina) dan sekaligus merupakan ius constituendum yang seyogianya membimbing pelaksanaan hukum positif secara keseluruhan dan hukum pidana Indonesia secara khusus. Adapun pemikiran manusia, termasuk filosof dan ahli hukum tidak dapat dijamin kebenarannya, karena manusia memiliki berbagai macam keterbatasan.

Berdasarkan uraian tersebut di atas, peneliti sangat setuju dengan penerapan pidana mati untuk delik-delik tertentu, seperti makar, narkotika, terorisme, pembunuhan berencana yang berujung pada hancurnya harkat, dan martabat manusia dengan cara menghilangkan nyawa orang lain secara kejam dan sadis atau dibarengi dengan tindak pidana lain (baik sebelum maupun setelah melakukan pembunuhan, seperti memperkosa, merampok, mencuri, memutilasi dan lain-lain), dan kejahatan serius lainnya. Karena pidana mati pada hakikatnya untuk melindungi harkat dan martabat manusia serta hak hidup manusia yang sangat luhur yang diberikan Tuhan kepada manusia. 


\section{PENUTUP}

Berdasarkan pembahasan di atas, dapat disimpulkan bahwa pada hakikatnya sanksi dalam hukum pidana Indonesia dan hukum pidana Islam dapat dibandingkan dengan meninjau hakikat sanksi dalam hukum pidana Indonesia adalah untuk menjaga/memelihara kemaslahatan individu. Sedangkan hakikat sanksi dalam hukum pidana Islam, adalah untuk menjaga/ memelihara kemaslahatan individu dan masyarakat.

\section{DAFTAR PUSTAKA}

Achmad Ali, 2008, Menguak Tabir Hukum, edisi kedua, Ghalia Indonesia, Bogor.

Ahmad Wardi Muslich, 2004. Pengantar dan Asas Hukum Pidana Islam Fikih Jinayah, Cet. I, Sinar Grafika, Jakarta.

Andi Hamzah, 1986. Suatu Tinjauan Ringkas Sistem Pemidanaan Indonesia, Jakarta. Andi

Zainal Abidin Farid, 1983 Bunga Rampai Hukum Pidana. Pradnya Paramita. Jakarta.

Bambang Waluyo, 2008. Pidana dan Pemidanaan, Sinar Grafika, Jakarta.

Bakri, H.M.K. 1986. Hukum Pidana Dalam Islam, Cet. III, Ramadhani, Solo.

Barda Nawawi Arief, 2005. Pembaharuan Hukum Pidana. Cet. I, Citra Aditya Bakti, Bandung.

Thalib, H. H. 2012. Sanksi Pemidanaan Dalam Konflik Pertanahan. Kencana.

M. Nurul Irfan, 2016. Hukum Pidana Islam, Ed. 1, Cet. 1, Amzah, Jakarta.

Solehuddin, 2004. Sistem Sanksi dalam Hukum Pidana; Ide Dasar Double Track Sustem dan Implementasinya, Cet. II, RajaGarfindo Persada, Jakarta. 